\title{
Tubular subdermal flap to dorsal nasal reconstruction in a dolichocephalic dog: case report
}

\author{
Retalho tubular subdérmico para reconstrução dorsal \\ nasal em cão dolicocefálico: relato de caso
}

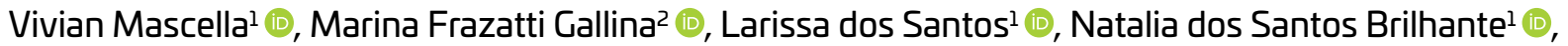 \\ Paulo Roberto Martin ${ }^{3}$ (D) Ivan Felismino Charas Santos ${ }^{2^{*}}$ (1)
}

\begin{abstract}
This case report described the use of tubular subdermal flap to dorsal nasal reconstruction of an old dolichocephalic dog. A nine-year-old Dachshund female dog-weighing $10 \mathrm{~kg}$ presented with deep and extensive wound in the dorsal nasal region was attended at veterinary clinic, Sorocaba city, São Paulo, Brazil. The reconstructive surgical procedure was performed in three stages with an interval time of 25 days, which included the preparation of the tubular subdermal flap; the advance of the flap to the region of the tissue defect, and the removal of excess flap. The region healed 14 days after the last stage. The tubular subdermal flap was effective for treating ulcerative epithelial wounds associated with interstitial lymphoplasmocyte dermatitis and vasculitis of the dorsal nasal region of an old Dachshund dog.
\end{abstract}

KEYWORDS: Healing; Nose; Reconstructive surgery; Skin; Wound.

\begin{abstract}
RESUMO: O relato de caso descreveu o uso de retalho subdérmico tubular para reconstrução dorsal nasal de um cão dolicocefálico idoso. Uma cadela da raça Dachshund, nove anos de idade, de $10 \mathrm{~kg}$ de massa corpórea, apresentando uma ferida extensa e profunda na região nasal dorsal, foi atendida na clínica veterinária na cidade de Sorocaba, São Paulo, Brasil. O procedimento cirúrgico reconstrutivo foi realizado em três etapas com intervalo de 25 dias, que incluiu a confecção do retalho tubular subdérmico; o avanço do retalho até a região do defeito e a retirada do excesso do retalho. A região cicatrizou 14 dias após à última etapa. O retalho tubular subdérmico foi eficaz no tratamento de feridas epiteliais ulcerativas associadas com dermatite linfoplasmocitária intersticial e vasculite da região nasal dorsal de um cão da raça Dachshund idoso.
\end{abstract}

PALAVRAS-CHAVE: cicatrização; Nariz; Cirurgia Reconstrutiva; Pele; Ferida.

\section{INTRODUCTION}

Tissue defects in dog's face that require reconstructive surgery are associated with trauma, chronic inflammation, chronic infections, resection of neoplasia, and congenital changes (HAAR et al., 2013; PAVLETIC, 2018a). The nasal region presents a greater difficulty for reconstruction due to the lack of tissue (PAVLETIC, 2018). Depending on the extent of the wound, forward subdermal flaps (COLOMBO et al., 2016; OLIVEIRA et al., 2019), rotation flaps (BUIKS; HAAR, 2013), transposition flaps (CHITI et al., 2018), axial flaps of mouth angular artery (BUIKS; HAAR, 2013; LOSINSKI et al., 2015), or axial flaps of superficial temporal artery
(BUIKS; HAAR, 2013) can be used. Tubular subdermal flap is an alternative procedure that reaches and covers wounds in regions with a lack of adjacent tissue (HEDLUND, 2008; PAVLETIC, 2018b).

Reports regarding the use of the tubular subdermal flap are less frequent in the literature (COLOMBO et al., 2016; POPE, 2006; WORLEY, 2016; CHITI et al., 2018; OLIVEIRA et al., 2019). In this context, this report case described the use of tubular subdermal flap to dorsal nasal reconstruction of an old dolichocephalic dog presented with ulcerative epithelial wound associated with interstitial lymphoplasmocyte dermatitis and vasculitis. 


\section{DESCRIPTION OF THE CASE}

A nine-year-old Dachshund non-spayed female dog weighing $10 \mathrm{~kg}$ was attended in a veterinary clinic, Sorocaba city, São Paulo, Brazil, with a history of a wound in the nasal region and no report of trauma. The progressive evolution was three months. According to the owner, the dog was housed, and no contact with other animals. At the physical examination, an ulcerative wound with $8.0 \mathrm{~cm} \times 3.0 \mathrm{~cm}$ in the dorsal nasal region was identified (Figure 1). No other alteration was identified, and a complete blood count (CBC), serum biochemical tests (SBT) [alanine aminotransferase (ALT), alkaline phosphatase (AP), urea (URE), creatinine (CREAT), gamma-glutamyl transferase (GGT), total protein (TP), albumin (ALB), and globulin (GLOB)], histopathology through incisional biopsy, microbiological examination of the wound; and X-ray of the nasal region were performed.

Cephalexin [30 mg/kg, orally (VO), BID] was prescribed for seven days. The X-ray did not show any bone changes, and $\mathrm{CBC}$ and SBT remained in the reference range. After seven days, the dog returned to veterinary clinics. The wound was more erosive $(10.0 \mathrm{~cm} \times 4.0 \mathrm{~cm})$ and exposure of the nasal cavity (Figure 2).

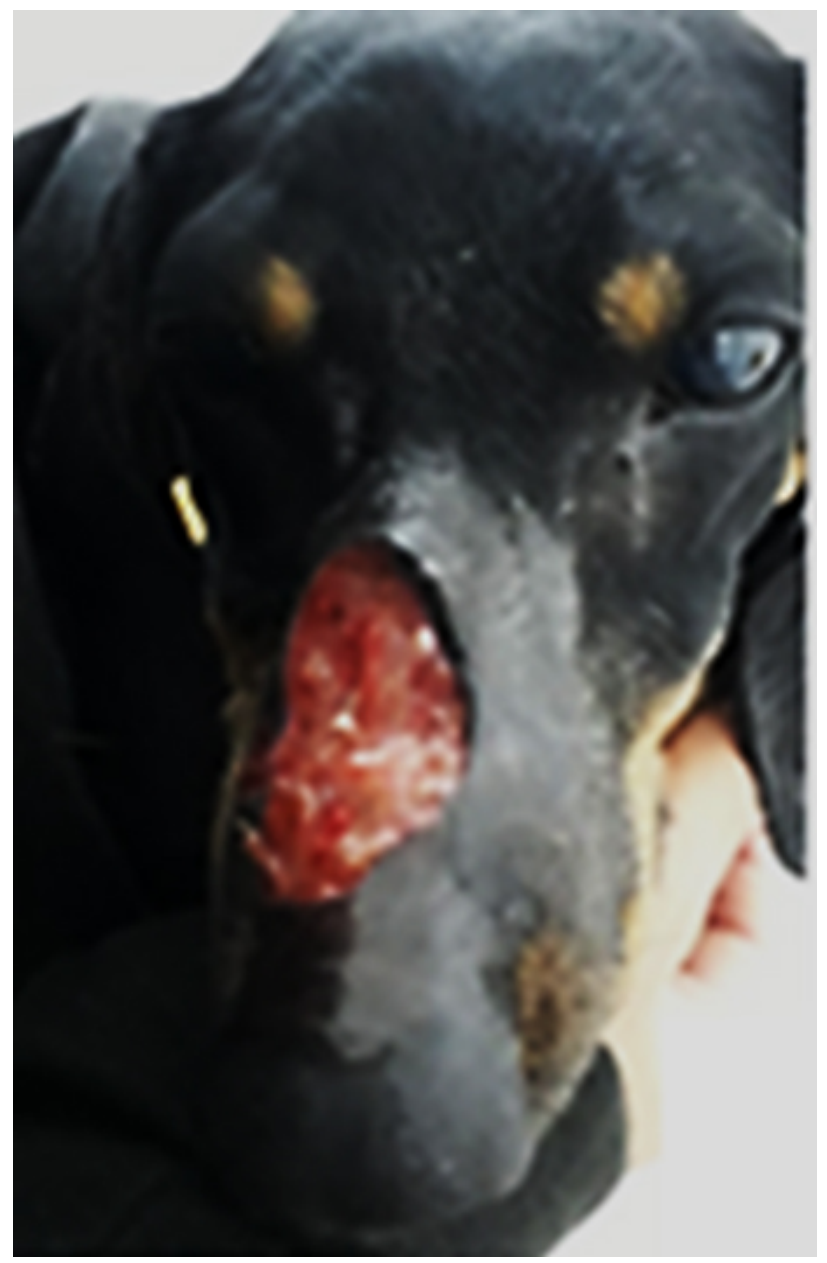

Figure 1. Ulcerative wound with $8.0 \mathrm{~cm} \times 3.0 \mathrm{~cm}$ in the dorsal nasal region (seven days before surgery).
The microbiological result was negative for bacteria or fungus. Histopathological examination showed severe lymphoplasmacytic interstitial dermatitis associated with vasculitis and epithelial ulceration. According to the blood samples, and wound evolution was decided to perform reconstructive surgical by using a tubular subdermal flap in three stages with an interval time of 25 days.

Anesthesia procedure was similar in all stages and included an 8-hour fasting and 4-hour water restriction. The premedication was performed with methadone $[0.7 \mathrm{mg} / \mathrm{kg}$, intramuscular (IM)], and anesthesia induction was done with midazolam $[0.2 \mathrm{mg} / \mathrm{kg}$, intravenously (IV)] and propofol (7 mg/kg, IV). Anesthesia was done with isoflurane by using a universal vaporizer mixed with oxygen $(100 \%)$ at a flow of $50 \mathrm{~mL} / \mathrm{kg} / \mathrm{min}$ in a semi-closed anesthetic circuit. During the surgical procedure, a Ringer solution (IV) was administered.

In all stages, the pre-surgical antisepsis was performed using chlorhexidine (2\%) followed by surgical antisepsis with an aqueous solution of chlorhexidine. During the surgery, the dog remained in ventral recumbence, and after it, the surgical wounds were treated with an aqueous solution of chlorhexidine

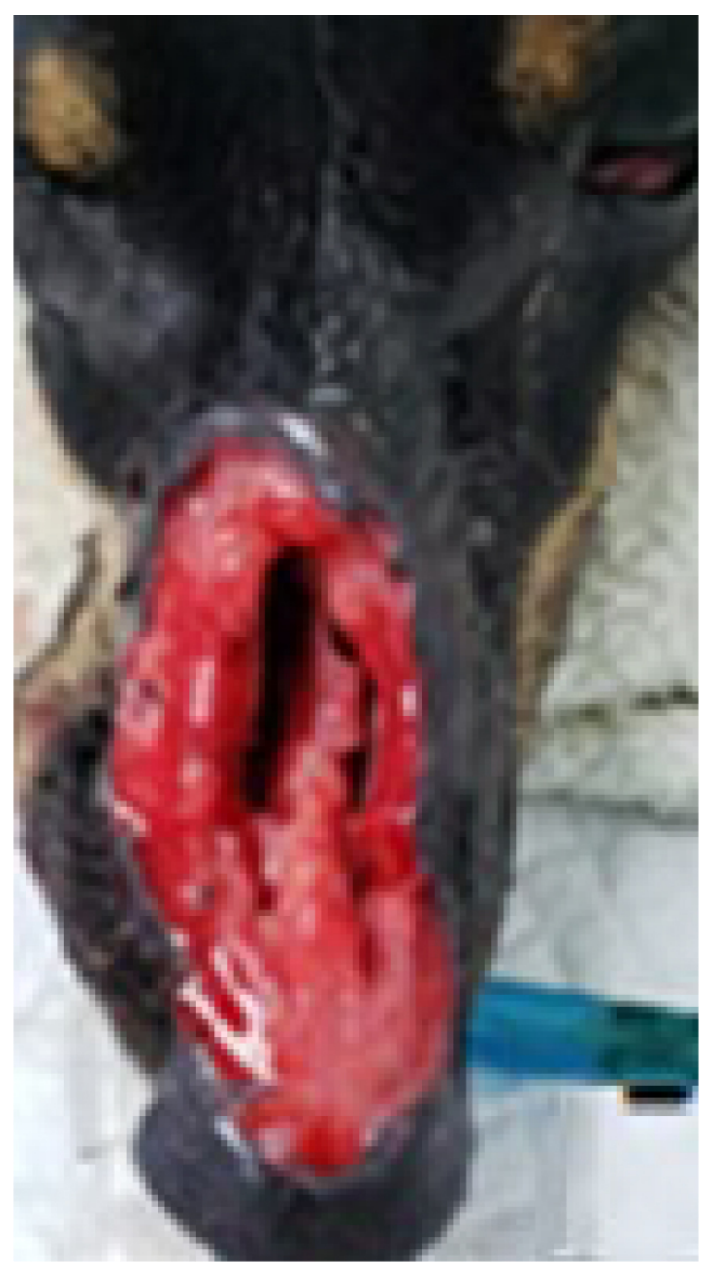

Figure 2. Erosive wound $(10.0 \mathrm{~cm} \times 4.0 \mathrm{~cm})$ with exposure of nasal cavity (surgery day). 
(TID) for 15 days. CBC and SBT (ALT, URE, CREAT, TP, ALB, GLOB) were performed 24-hours before each surgery, and no significant changes were identified.

\section{$1^{\text {st }}$ stage}

An extensive hair clipped of the cervical and cervicothoracic region was performed. Two parallel skin incisions with $8.0 \mathrm{~cm}$ apart were made using a scalpel (blade $\mathrm{n}^{\circ} .22$ ), and $30.0 \mathrm{~cm}$ incision length was determined by the distance between the occipital region and the third thoracic vertebra (Figure 3A). An in-depth dissection using Metzembaum scissors, preserving the subdermal plexus, was performed and the skin was released and created marginal tube sutures using a 3-0 non-absorbable monofilament nylon suture in a simple interrupted pattern (Figure 3B). The skin close was performed using the same suture. Cephalexin $(30 \mathrm{mg} / \mathrm{kg}$, $\mathrm{VO}, \mathrm{BID})(\mathrm{VO})$ for 21 days; meloxicam $(0.1 \mathrm{mg} / \mathrm{kg}$, $\mathrm{VO}$, SID) for four days, and dipyrone $(25 \mathrm{mg} / \mathrm{kg}$, VO, TID) for five days were prescribed.

\section{$2^{\text {nd }}$ stage}

No complications were observed between the first and second stages. In the second stage, the distal extremity of the subdermal tube was removed and implanted on the defect using a 3-0 polyglecaprone suture using a simple interrupted suture pattern (Figure 4A). During implantation, the tube's distal extremity was cut with a scalpel to open the lumen and increase coverage in the defect area. An anchoring suture using a 3-0 non-absorbable monofilament nylon suture was performed in the frontal region of the head to avoid excessive movement of the tube. Antibiotics and analgesics were the same used in the first stage. After 14 days, wound dehiscence was observed in the defect (Figure 4B). The dog was anesthetized, and two simple interrupted sutures were conducted. Meloxicam

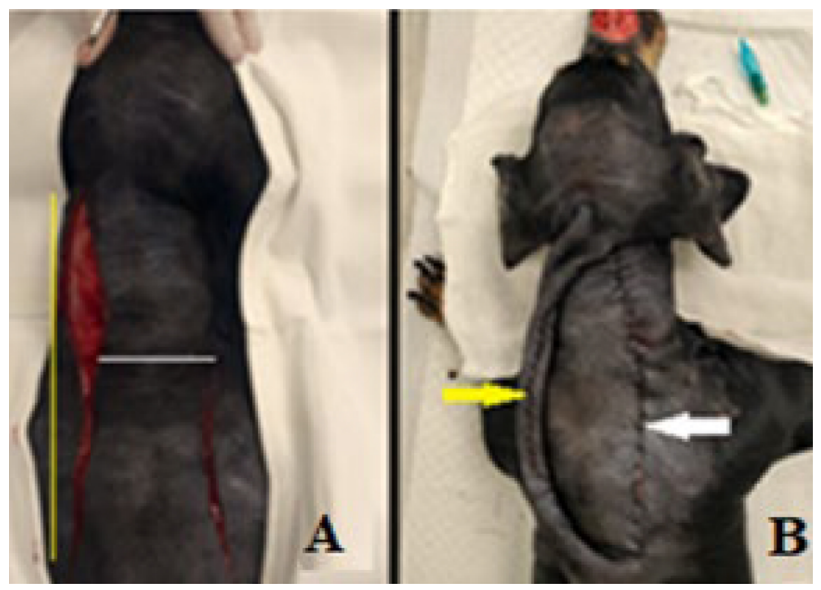

Figure 3. Two parallel skin incisions with $8.0 \mathrm{~cm}$ apart (white line), and $30 \mathrm{~cm}$ in length (yellow lines) (A). Subdermal tube (yellow arrow) and the donor site sutured (white arrow) (1 $1^{\text {st }}$ stage) (B).
$(0.1 \mathrm{mg} / \mathrm{kg}, \mathrm{VO}, \mathrm{SID})$ was prescribed for five days, and local treatment with sterile saline solution (0.9\%) (TID) was arranged for 10 days.

\section{$3^{\text {rd }}$ stage}

The subdermal tube was removed by the incision of the proximal extremity, and suture with 3-0 non-absorbable monofilament nylon using a simple interrupted pattern suture was performed. During this time, was identified the presence of alopecia and small wounds in the region of the anchorage suture (Figure 5A), and was prescribed local application of chlorhexidine digluconate ointment (BID). The animal returned for a follow-up examination 14 days after the last surgery, and no alopecia was observed (Figure 5B). The flap was healed, and the stitches were removed. The dog was released with no evidence of local recurrence 90 days postoperatively.

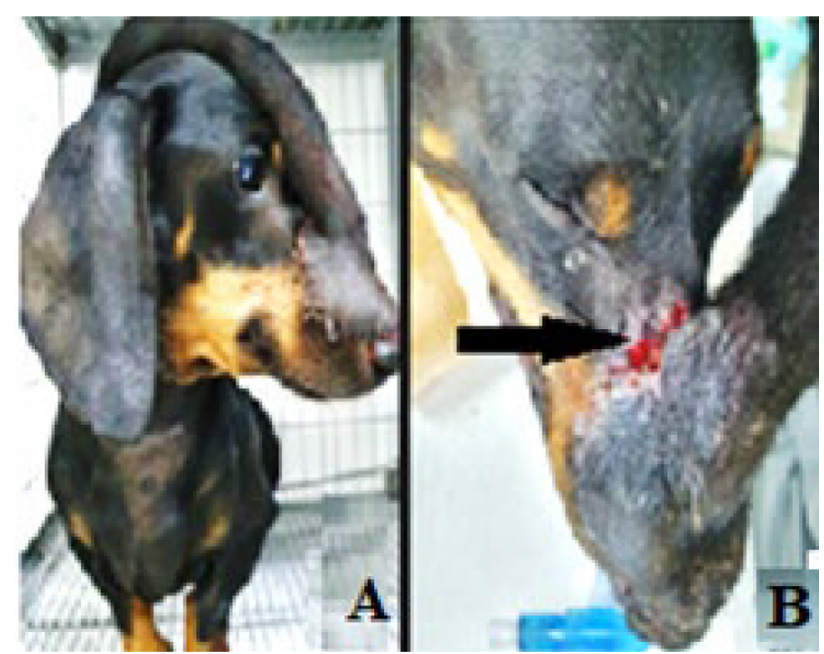

Figure 4. Distal extremity of the subdermal tube removed, and implanted on the defect ( $2^{\text {nd }}$ stage) (A). Wound dehiscence (B).

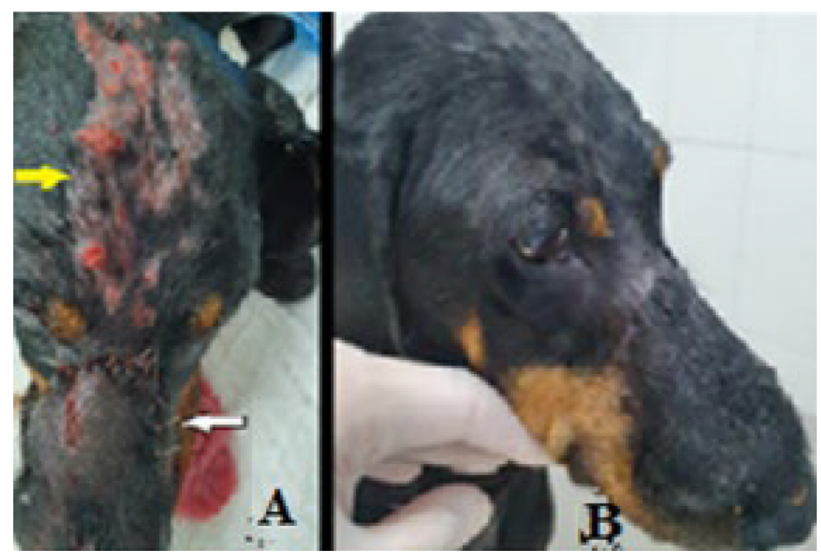

Figure 5. Alopecia and small wounds in the region of the anchorage suture (yellow arrow), and the sutures of the proximal extremity of the tube after incision (white arrow) ( $3^{\text {rd }}$ stage) $(A)$, fourteen days after the last surgery. 


\section{DISCUSSION}

This case report described the use of tubular subdermal flap in a wound in the dorsal nasal region of an old dolichocephalic dog since this region is lack tissue, corroborated with literature (CORREA et al., 2013; HAAR et al., 2013; PAVLETIC, 2018a). In human patients, the tubular flap is widely used in the rostral nasal reconstruction, however, reports regarding the use of a tubular subdermal flap in dogs are less frequent in the literature (COLOMBO et al., 2016; POPE, 2006; WORLEY, 2016; CHITI et al., 2018; OLIVEIRA et al., 2019). The breed's dog was classified as a dolichocephalic breed, which are dogs with a more slanted forehead and long and narrow nose, giving them more predisposition to be affected by aspergillosis and nasal neoplasia (CHITI et al., 2018; WORLEY, 2016). However, the microbiological exams were negative for fungal infection and neoplasia.

According to the histopathological diagnosis, the wound was associated with trauma followed by idiopathic vasculitis that can lead to tissue ischemia and consequently epidermal ulceration (INNERA, 2013). This trauma has led to an inflammatory process resulting from an intensified immune response that was associated with idiopathic etiology, similarly cited by Innera (2013). However, cutaneous leishmaniasis should be considered as a differential diagnosis, since it manifests as localized skin lesions in the mucous membranes (mouth and nose) that either heal or become chronic, leading to significant tissue destruction and disfigurement (SASANI et al., 2016). However, these wounds can spontaneously regress (BRACHELENTE et al., 2005; SASANI et al., 2016), unlike this case.

The surgical procedure using a subdermal tubular flap was performed according to the literature (HAAR et al., 2013; PAVLETIC, 2018a) and included the absence of changes in blood exams and X-rays; wound location; availability of donor tissue; and distance between the recipient and donor area. Other subdermal techniques for the nasal region have been cited by the literature (BUIKS; HAAR, 2013; CHITI et al., 2018; COLOMBO et al., 2016; LOSINSKI et al.,
2015; OLIVEIRA et al., 2019). However, the tubular subdermal flap allows us to reach the wound with a lack of adjacent tissue, similar to reported by Hedlund (2008) and Pavletic (2018b). Pope (2006) related this technique to cases of extensive wounds in the dorsal nasal region but with the disadvantage associated with the necessity of more than one surgical procedure, similar to this report. The tubular subdermal flap was made using two pedicles and sutured in a tube before being transferred to a wound (HEDLUND, 2008; PAVLETIC, 2018b). The surgery was performed at an interval of 25 days due to the presence of vasculitis, different from the literature (HEDLUND, 2008; PAVLETIC, 2018b), which cited transfer around 14 to 21 days to ensure adequate blood supply to the flap through neovascularization. Alternatively, according to the size of the wound, the distance between the donor tissue and the wound, and tissue retraction, the flap was performed with $8.0 \mathrm{~cm}$ wide and $30.0 \mathrm{~cm}$ long with preservation of the local subdermal plexus. Hedlund (2008) and Worley (2016) mentioned that the tubular flaps must have between 2.0 and $3.0 \mathrm{~cm}$ of excess tissue than the dimensions of the wound, and should not exceed six to eight times concerning the width regarding flap contraction.

The defect was closed without tissue tension, however wound dehiscence was observed 14 days after the second stage of surgery. In this way, the anchoring sutures were necessary to avoid excessive movement of the flap, and the suture pattern used in the flap margin was performed as recommended by Hedlund (2008) and De Nardi et al. (2015), to avoid necrosis as does not compromise local flow and angiogenesis. The limitation of this case report was associated with the impossibility of dog's owner to perform a tomography exam that is more sensible to identify bone alteration, and not performing the leishmaniosis test.

\section{CONCLUSIONS}

The subdermal tubular flap is effective for treating ulcerative epithelial wounds associated with interstitial lymphoplasmocyte dermatitis and vasculitis of the dorsal nasal region of an old dolichocephalic dog.

\section{REFERENCES}

BRACHELENTE, C.; MÜLLER, N.; DOHERR, M.G.; SATTLER, U.; WELLE, M. Cutaneous leishmaniasis in naturally infected dogs is associated with a Thelper-2-biased immune response. Veterinary Patholology, v. 42, n. 2, p. 166-175, 2005.

BUIKS, S. C.; HAAR, G. T. Reconstructive techniques of the facial area and head. In: KIRPENSTEIJN, J.; HAAR, C. T. Reconstructive Surgery and Wound Management of Dog e Cat. London: Manson Publishing Ltda, 2013. p. 95-115.

CHITI, L. E. et al. Lip-to-nose flap for nasal plane reconstruction in dogs: a cadaveric and in vivo feasibility study. Veterinary Surgery, v. 47, n. 8, p. 1101-1105, 2018.
COLOMBO, B. B. et al. Reconstrução cirúrgica com retalho pediculado de avanço após exérese de melanoma cutâneo facial em um cão relato de caso. Revista Brasileira de Medicina Veterinária, v. 38, ก. 2, p. 128-132, 2016.

CORREA, B. J. et al. The forehead flap: the gold standard of nasal soft tissue reconstruction. Seminars in Plastic Surgery, v. 27, n. 2, p. 96-103, 2013.

DE NARDI, A. B. et al. Técnicas reconstrutivas em membros torácicos. In: CASTRO, J. L. C. et al. (Ed.). Princípios e técnicas de cirurgias reconstrutivas da pele de cães e gatos (atlas colorido). Curitiba: Medvep, 2015. p. 132-137. 
HAAR, G. T. et al. Introduction. In: KIRPENSTEIJN, J.; HAAR, G. T. (Ed.). Reconstructive Surgery and Wound Management of Dog e Cat. London: Manson Publishing Ltda, 2013. p. 13-19.

HEDLUND, C. S. Cirurgia do Sistema Tegumentar. In: FOSSUM, T. W. (Ed.). Cirurgia de Pequenos Animais. 3. ed. Rio de Janeiro: Elsevier, 2008. p. 159-224.

INNERA, M. Cutaneous vasculitis in small animals. Veterinary Clinics of North America:Small Animal Practice, v. 43, n. 1, p. 113-134, 2013.

LOSINSKI, S. L. et al. Versatility of the angularis oris axial pattern flap forfacial reconstruction. Veterinary Surgery, v. 44, p. 930-938, 2015.

OLIVEIRA, M. C. C. P. et al. H-plastia com flap de avanço para reconstrução de região nasal após exérese de nódulo em cão. Ciência animal, v. 29, n. 4, p. 69-72, 2019.

PAVLETIC, M. M. Facial reconstruction. In: PAVLETIC, M. M. (Ed.). Atlas of small animal wound management and reconstructive surgery. 4. ed. Hoboken: Wiley Blackwell, 2018a. p. 493-551.
PAVLETIC, M. M. Distant flap techniques. In: PAVLETIC, M. M. (Ed.). Atlas of small animal wound management and reconstructive surgery. 4th ed. Hoboken: Wiley Blackwell, 2018b. p. 395-416.

POPE, E. R. Head and facial wounds in dogs and cats. The Veterinary Clinics of North America: Small Animal Practice, v. 36, n. 4, p. 793-817, 2006.

SASANI, F.; JAVANBAKHT, J.; SAMANI, R.; SHIRANI, D. Canine cutaneous leishmaniasis. Journal of Parasitic Diseases, v. 40, ก. 1, p. 57-60, 2016.

VÉLEZ, I.D.; CARRILLO, L.M.; LÓPEZ, L.; RODRÍGUEZ, E.; ROBLEDO, S.M. An epidemic outbreak of canine cutaneous leishmaniasis in Colombia caused by Leishmania braziliensis and Leishmania panamanensis. American Journal of Tropical Medicine and Hygiene, v. 86, n. 5, p. 807-811, 2012.

WORLEY, D. R. Nose and nasal planum neoplasia, reconstruction. Veterinary Clinics of North America: Small Animal Practice, v. 46, n. 4, p. 735-750, 2016. 